\title{
OPTIMALISASI PERUBAHAN PERILAKU DAN PEMBERDAYAAN MASYARAKAT DALAM KASUS TUBERKULOSIS PARU UNTUK PENINGKATAN DERAJAT KESEHATAN DI KECAMATAN BARADATU KABUPATEN WAY KANAN
}

\author{
Evi Kurniawaty ${ }^{1}$, Winda Trijayanthi Utama ${ }^{2}$, Nuriah $^{3}$, Suharyani $^{4}$, Silvia Andriani ${ }^{5}$ \\ 1,2,3,4,5 Universitas Lampung, Lampung, Indonesia \\ evikurniawatyherlambang@yahoo.com,wtrijayanthi@gmail.com,nuriahfkunila@gmail.com, \\ yanisoedarmo@gmail.com silviaandriani12@gmail.com
}

\begin{abstract}
Abstrak
Pengabdian Kepada Masyarakat (PKM) di Kecamatan Baradatu Kabupaten Way Kanan dilatar belakangi oleh adanya data permasalahan TB sebagai potensi desa. Kasus Tuberkulosis di Kecamatan Baradatu cukup banyak, tetapi yang menjalani pengobatan sangat sedikit. Untuk menurunkan angka kejadian Tuberkulosis Paru, diperlukan peran serta aktif dari berbagai pihak yang terkait seperti Puskesmas dan kader kesehatan. Kader kesehatan perlu memiliki kemampuan dalam memberikan pendidikan kesehatan dan rujukan. Tujuan diadakannya pelatihan kader kesehatan tentang deteksi dini Tuberkulosis Paru adalah untuk meningkatkan pengetahuan dan kemampuan kader. Dalam rangka meningkatkan pengetahuan dan kemampuan kader memberikan pendidikan kesehatan tentang Tuberkulosis Paru maka perlu diadakan pelatihan. Salah satu pelatihan yang penting diberikan adalah deteksi dini Tuberkulosis Paru sesuai dengan potensi yang ada di Kecamatan Baradatu Kabupaten Way Kanan sebagai daerah mitra Kerjasama Desa Binaaan Universitas Lampung. Pengabdian Kepada Masyarakat ini dilaksanakan terhitung Bulan Maret sampai dengan Septemberr 2020, bertempat di Kecamatan Baradtu Kabupaten Way Kanan dengan sasaran para kader kesehatan. Pelatihan dimulai dengan pendataan kader, pelatihan, pendampingan, dan evaluasi kegiatan. Kegiatan PKM ini sangat bermanfaat untuk para kader kesehatan karena menambah pengetahuan mereka mengenai penyakit Tuberkulosis Paru, khususnya kemampuan melakukan deteksi dini untuk meneruskan program tersebut disarankan pihak Puskesmas untuk dapat menindaklanjuti data baru penderita Tuberkulosis Paru yang telah diperoleh oleh para kader.
\end{abstract}

Kata kunci: kader, deteksi dini, tuberculosis

\section{PENDAHULUAN}

Angka kejadian Tuberkulosis (TB) di Indonesia cukup tinggi. Berdasarkan data WHO pada tahun 2010, Indonesia masih menduduki peringkat lima besar dengan jumlah penderita TB sebesar 429.000 orang, setelah India, Cina, Afrika Selatan, dan Nigeria (WHO, 2010). Berdasarkan data Riskesdas 2007, jumlah penderita TB di Indonesia mencapai 0,7\% dari jumlah total penduduk dan khususnya di Jawa Barat tercatat sebesar $0,9 \%$ dari jumlah populasi penduduk.

TB paru merupakan infeksi yang disebabkan oleh bakteri Mycobacterium tuberculosis (Schweon, 2009), sejenis kuman berbentuk batang dengan ukuran panjang $1-4 / \mu \mathrm{m}$, dan tebal $0,3-$ $0,6 / \mu \mathrm{m}$. Gejala paling umum pada penderita tersangka TB paru meliputi: 1) Batuk yang terus menerus dan berdahak selama 3 minggu atau lebih,
2) Dahak bercampur darah (haemoptoe), 3) Sesak nafas dan rasa nyeri pada dada, 4) Lemah badan, kehilangan nafsu makan dan berat badan menurun, rasa kurang enak badan (malaise), dan 5) Berkeringat malam tanpa disertai kegiatan, demam meriang lebih dari 1 bulan (Kurniawati, 2011).

Pada Provinsi Lampung jumlah penderita Tuberkoolosis meningkat setiap tahun nya, namun sebaliknya angka cangkupan pengobatan sangat rendah khususnya pada Kecamatan Baradatu Kabupaten Way Kanan hanya $3 \%$ penderita yang melakukan pengobatan. Tinggi nya kasus penderita Tuberkolosis disebabkan antara lain ketidakpatuhan terhadap program pengobatan maupun pengobatan yang tidak edukatif.

Menurut Badan Kesehatan Dunia (WHO) penyakit ini dibagi menjadi 4 kategori, mulai kategori I yang ditujukan terhadap kasus baru dengan sputum positif dan kasus baru dengan batuk tuberkulosis berat sampai kategori IV yang ditujukan terhadap tuberkulosis kronik. Namun, klasifikasi yang sering

$$
\begin{array}{l|l}
\text { Lingkungan Hidup dan Kebencanaan } & 664
\end{array}
$$


dipakai di Indonesia adalah berdasarkan kelainan klinis, radiolis dan mikrobiologis:1) Tuberkulosis paru, 2) Bekas tuberkulosis paru, dan 3) Tuberkulosisparu tersangka. Klasifikasi ini dikategorikan yang terobati dan tersangka yang tidak diobati. Sputum BTA pada yang terobati menunjukkan hasil negatif tetapi tanda-tanda lain positif. Sedangkan sputum pada yang tidak terobati, negatif dan tanda-tanda lain juga meragukan (Mansjoer, 2001).

Berdasarkan latar belakang diatas, maka penulis tertarik untuk melakukan kegiatan Pelatihan Kader Kesehatan Tentang Deteksi Dini Tuberkulosis Paru Di Kecamatan Baradatu Kabupaten Way Kanan.

\section{METODE}

Metode pelaksanaan kegiatan pada kegiatan ini adalah pendataan kader, pelatihan kader, dan evaluasi serta membuat rencana tindak lanjut (RTL).

Pelatihan kader kesehatan di Kecamatan Baradatu Kabupaten Way Kanan diawali oleh kegiatan berupa pendataan kader. Hal ini ditujukan untuk mengetahui sumber daya yang dimiliki daerah yang dapat diberdayakan dalam rangka meningkatkan derajat kesehatan masyarakat. Setelah diperoleh data kader di Kecamatan Baradatu selanjutnya ditetapkan para kader yang bersedia dan akan mengikuti pelatihan.

Kegiatan PHBS ( Prilaku Hidup Bersih dan Sehat) sebelum dimulai nya kegiatan untuk meningkatkan derajat kesehatan dengan perubahan prilaku hidup sehat. Kegiatan selanjutnya pre test diberikan sebelum pelaksanaan pelatihan guna mengetahui sejauh mana tingkat pengetahuan kader mengenai TB. Pre test diberikan berupa beberapa pertanyaan mengenai TB dan hasilnya menunjukan bahwa para kader perlu mendapat penyegaran ilmu mengenai TB. Pelatihan diberikan dengan pemberian

Pemberian materi pelatihan menggunakan media infokus dengan metode ceramah dua arah dan penyebaran leaflet. Sebelum dilakukan pelatihan, dilakukan pre test terlebih dahulu dengan tujuan untuk mengetahui sejauh mana pengetahuan para kader mengenai TB. Hasil pre test menunjukan bahwa pengetahuan para kader mengenai TB masih kurang meskipun beberapa dari para kader menyatakan pernah mendapat informasi mengenai TB dari Puskesmas.

Evaluasi pelaksanaan pemberian materi oleh kader kesehatan kepada masyarakat di Kecamatan Baradatu secara umum didapatkan hasil bahwa para kader menunjukan peningkatan kemampuan. Khalayak sasaran dalam pelaksanaan kegiatan ini adalah para kader kesehatan di Kecamatan Baradatu Kabupaten Way Kanan

\section{HASIL DAN PEMBAHASAN}

Pada tahap persiapan, kegiatan yang pertama dilakukan adalah menyelesaikan proses perijinan kepada pihak Kecamatan Baradatu Kabupaten Way kanan. Proses perijinan dilakukan oleh Ketua Pengabdian dengan Kepala Dinas Kesehatan Way Kanan. Persiapan berikutnya adalah menghubungi Kepala Dinas Kesehatan dan Bapak Camat Kecamatan Baradatu serta menyampaikan rencana program pelaksanaan deteksi dini TB di Kecamatan Baradatu. Kepala Dinas kesahatan memberikan persetujuan bagi tim untuk melaksanakan kegiatan pelatihan. Selanjutnya dosen dibantu maha- siswa, melakukan pendataan kader di Kecamatan Baradtu. Hasil pendataan kader diperoleh hasil jumlah kader yang bersedia menjadi kader kesehatan tidak memenuhi target 25 orang dari setiap desa.

Pada tahap kerja, yakni pelatihan deteksi dini, dilakukan pre tes terlebih dahulu. Pelaknsaan pre tes berupa pemberian pertanyaan mengenai $\mathrm{TB}$, dengan tujuan untuk mengetahui sejauh mana pengetahuan kader mengenai TB. Selanjutnya dilaksanakan pelatihan selama dua hari. Materi yang diberikan adalah mengenai cara mengenali tanda dan gejala TB, dampak bagi penderita dan keluarga, serta bagaimana cara melakukan deteksi dini pada penderita. Pelatihan dihadiri oleh 25 kader dari masing-masing desa, meliputi ibu bidan setempat.

Mediasi atau pendampingan dilakukan terhadap para kader untuk mendeteksi adanya penderita $\mathrm{TB}$ di masyarakat. Beberapa penderita terjaring dalam pendeteksian dini ini. Selanjutnya dilakukan evaluasi kegiatan terhadap kegiatan yang telah dilakukan para kader. Hasil evaluasi didapatkan data para kader sangat antusias bertanya dan ingin mengetahui mengenai TB.

Faktor pendorong dalam kegiatan ini adalah antusias para kader dalam mengikuti pelatihan. Selain itu kepala Dinas Kesehatan sangat besar pula dalam memberikan motivasi kepada tim dan para kader untuk dapat melaksanakan kegiatan ini. Banyak pertanyaan yang diajukan oleh para kader.

Faktor penghambat dalam kegiatan ini adalah keterbatasan karena pandemi covid dalam pelaksanaan kegiatan, sehingga tim sedikit mengalami kesulitan ketika menjelaskan materi. Pemberian materi diberikan melalui ceramah dan tanya jawab, selanjutnya memberikan simulasi deteksi dini. Di samping itu, para kader tidak dapat sepenuhnya berkonsentrasi dalam pelaksanaan deteksi dini TB ini 
dikarenakan sedang difokuskan pula pada program pengobatan TB.

Peningkatan pengetahuan dapat diketahui dari adanya perbedaan pengetahuan sebelum dan sesudah diberikan pendidikan materi. Oleh karena itu, pre test dan post test yang dilakukan memberikan gambaran adanya perubahan tersebut, apakah meningkat atau tetap. Hasil pre post test menunjukan adanya peningkatan

\section{KESIMPULAN}

Secara umum, kegiatan pelatihan ini berhasil. Hal ini ditunjukan adanya peningkatan pengetahuan kader mengenai TB bahkan menjadi mampu untuk melakukan deteksi dini. Hal ini dikarenakan para kader yang antusias mengikuti pelatihan. Untuk meningkatkan kemampuan kognitif dan keterampilan para kader sebaiknya dilakukan program secara berkelanjutan oleh petugas di Puskesmas.

\section{UCAPAN TERIMAKASIH}

Terima kasih penulis sampaikan kepada Lembaga Penelitian dan Pengabdian kepada Masyarakat (LPPM) Universitas Lampung yang telah mendanai sepenuhnya pengabdian ini melalui DIPA BLU 2020 .

\section{REFERENSI}

Badan Penelitia dan Pengembangan Kesehatan.2008. Laporan Hasil Riset Kesehatan Dasar(RISKESDAS) Provinsi Jawa Barat 2007. Jakarta WHO 2010, Multidrug and extensively drug-resistant TB (M/XDR-TB): 2010 global report on surveillance and response. WHO: Geneva.

Aurora, V.K., Johri, Amit., Varma, Ramesh., \& Pamani. 1992. Post-treatment adjustment problems and coping mechanisms in pulmonary tuberculosis patients. Ind. J. Tub. 39:181.

Aydin, I.O.\& Ulu ahin, A. 2001 Depression, anxiety comorbidity, anddisability in tuberculosis and chronic obstructive pulmonarydisease patients: applicability of GHQ-12. Gen Hospital Psychiatry, 23: 77-83.

Aye', R., Wyss,K.,Abdualimova, H. \& Saidaliev, S. 2011.Factors determining household expenditure ftuberculosisand coping strategies in Tajikistan. Tropical Medicine and International Health. 16 (3): 307-313

Barnhoorn, F. \& Adriaanse, H. 1992. In search of factors responsible fornoncompliance among tuberculosis patients in Wardha District,India. Social Science Medicine, 34: 291-306.

Habibah 2009, Mekanisme Koping Penderita TBC Paru Menghadapi Penyakitnya Di Wilayah Puskesmas Bergas. Undergraduate thesis: Universitas Diponegoro.

Jong, K.2011 Psychosocial and mental heanth interventions in areas of massive violence. 2 ed. Medecins san frontier. Amsterdam: Rozenberg Publishing Services.

Padayatchi, A., Daftary, T., Moodley, R., Madansein, A., Ramjee 2010. Case series of the longterm psychosocial impact ofdrug-resistant tuberculosis in HIV-negative medical doctors International Journal Tuberculosis LungDisesase, 14 (8): 960-966.

Schweon, S J. 2009. Tuberculosis Update. J Radiol Nurs, 28: 12-19.

Thomas, C. 2001. Final Report To The National Health Service Executive. North West.

Vega, P A., Sweetland, A., Acha, J., Castillo, H., Guerra, D., Smith, M., Fawzi, C., \& Shin, S. 2004. Psychiatric issues in the management of patients with multidrug-resistant tuberculosis. International Journal Tuberculosis Lung Disesase,8 (6): 749-759.

WHO. 2010. Multidrug and extensively drugresistant TB (M/XDR-TB): 2010 global report on surveillance and response. 